\section{Sexual and reproductive health of women living with HIV in Southern Brazil}

\author{
Saúde sexual e reprodutiva de mulheres vivendo \\ com HIV no Sul do Brasil
}

\author{
Salud sexual y reproductiva de mujeres viviendo \\ con VIH en el sur de Brasil
}

1 Programa de Pós-graduação
em Epidemiologia,
Universidade Federal do
Rio Grande do Sul, Porto
Alegre, Brasil.
2 Grupo Hospitalar
Conceição, Porto Alegre,
Brasil.
Correspondence
L. B. Teixeira
Programa de Pós-graduação
em Epidemiologia,
Universidade Federal do Rio
Grande do Sul.
Rua Ramiro Barcelos 2400,
Porto Alegre, RS 90035-003,
Brasil.
luciana.bteixeira@gmail.com

Abstract

This cross-sectional study focused on the sexual and reproductive health of women living with HIV, by age group, in the city of Porto Alegre, Rio Grande do Sul State, Brazil. The sample consisted of 691 women. Differences were observed in number of pregnancies and number of children. History of illicit drug use was more frequent in the 18-34-year age group, and exchanging sex for money was more frequent among women 18-29 years of age. This sample of women living with HIV treated in specialized public services in Southern Brazil showed a socioeconomic profile and sexual behavior that did not match the pattern typically identified in the process of "feminization" of the epidemic (with a majority of poor women with low schooling and a limited number of sexual partners). The study provides evidence of factors characterizing women's vulnerability to HIV infection, differing by age and raising specific demands for healthcare services.

Sexual and Reprodutive Health; HIV; Women; Sexual Behavior
Luciana Barcellos Teixeira 1,2

Flávia Bulegon Pilecco 1

Alvaro Vigo 1

Daniela Riva Knauth 1

\section{Resumo}

Estudo transversal que analisou o comportamento, em termos de saúde sexual e reprodutiva, adotado pelas mulheres vivendo com HIV, segundo a faixa etária, na cidade de Porto Alegre, Rio Grande do Sul, Brasil. A amostra foi constituída por 691 mulheres. Foram observadas diferenças quanto ao número de gestações e filhos. O uso de drogas ilícitas durante a vida foi mais frequente na faixa dos 18 aos 34 anos, e a prática de sexo por dinheiro foi mais frequente entre as mulheres de 18 a 29 anos. As mulheres vivendo com HIV atendidas nos serviços públicos especializados no Sul do Brasil apresentam um perfil socioeconômico e de comportamento sexual que não corresponde ao padrão tipicamente identificado no processo de feminização da epidemia, no qual se destacam, particularmente, mulheres pobres, com baixa escolaridade e baixo número de parceiros sexuais. O estudo fornece evidências de que alguns fatores que caracterizam a vulnerabilidade das mulheres à infecção pelo HIV são bastante diferenciados quando consideramos a faixa etária, o que implica em demandas específicas de atenção nos serviços de saúde.

Saúde Sexual e Reprodutiva; HIV; Mulheres; Comportamento Sexual 


\section{Introduction}

Although significant strides have been documented in the last decade in the response to AIDS 1, cases among women have increased progressively since the beginning of the epidemic. This process, known as "feminization" of the epidemic 2, has been documented both in Brazil and in other countries 3 . Globally, according to estimates by the Joint United Nations Program on HIV/AIDS (UNAIDS), women now represent some $50 \%$ (95\%CI: 48-53) of individuals over 15 years of age living with HIV, a proportion that varies considerably by region. Factors related to the HIV epidemic include economic, social, and cultural inequalities, especially in relation to HIV infection in females.

The highest HIV prevalence rates in women are in Sub-Saharan Africa and the Caribbean. The last decade showed a slight increase in the proportion of women among persons living with HIV in Latin America, North America, and Western and Central Europe 2. In Latin America, the proportion of women increased from $32 \%$ (95\%CI: 26-41) in 2001 to $35 \%$ (95\%CI: 29-41) in 2010. Brazil has one-third of the persons living with HIV in Central and South America 2, and from the first reported AIDS case until 2011, 34.6\% of cases were in women, the majority of whom were of childbearing age 4 .

The Brazilian public health system mounted a successful response to the AIDS epidemic, receiving international recognition 5 through promotion of universal access to antiretroviral therapy, preventive measures, and actions to promote human rights with broad participation by civil society 6 . Nevertheless, the national data showed an $82 \%$ increase in the number of reported AIDS cases in the female population from 1995 to 2005 7. The sex ratio decreased systematically, from 26.7 males per female in 1985 to 1.7 male per female in 2010 . Thus, special attention has been given in recent years to the increase in women infected with HIV through the Plan to Deal with Feminization of the AIDS Epidemic and other STDs 7 .

Epidemiological data point to Rio Grande do Sul (the southernmost State of Brazil) as the State with the highest proportion of AIDS cases in women. Since 2001, women have represented more than $40 \%$ of reported cases. In 2009 this proportion increased to $46 \%$ (Departamento de Informática do SUS. Casos de AIDS identificados no Rio Grande do Sul. http:/ / www2.aids.gov. br/cgi/deftohtm.exe?tabnet/rs.def, accessed on 13/Dec/2011), similar to the rates reported by UNAIDS in African countries 2. Of the women identified in 2009, $79 \%$ were in the 15-to-49-year age group, and the predominant exposure category was heterosexual contact (Departamento de Informática do SUS. Casos de AIDS identificados no Rio Grande do Sul. http: / / www2.aids.gov. br/cgi/deftohtm.exe?tabnet/rs.def, accessed on $13 / \mathrm{Dec} / 2011$ ). In the younger age groups (14 to 29 years), the number of women is practically double that of men 8 .

The Global Plan launched by UNAIDS emphasizes that women living with HIV are the center of the response to the epidemic 9 . Prevention of HIV infection in women of childbearing age is seen as a vital step for reducing new infections in children and requires the reduction of HIV incidence in women 15 to 49 years of age 1 and the proper supply of family planning and complementary services to women living with HIV 2. This approach had already been identified in previous years for achieving internationally negotiated goals. In order to upgrade healthcare for women living with HIV, some criticism has been aimed at certain health policies. For example, with the introduction of the protocol to prevent mother-to-child transmission, the concept of women's health has been heavily associated with childbearing. In this sense, public policies have fallen short of offering comprehensive healthcare for women living with HIV that take into account their sexual characteristics and reproductive decisions 10. Part of this deficit is due to the prioritization, particularly in developing countries, of maternal-child health policies whose main objective has been to reduce infant mortality, and which are still in force today. Meanwhile, the association between AIDS and so-called "risk groups" still persists in the minds of health professionals and hinders the identification of married women and/or women with children and living with HIV.

The increase in the number of women infected with HIV and the current increase in life expectancy provided by antiretroviral therapy create the need for greater knowledge on sexual and reproductive health decisions by these women. Various studies have attempted to evaluate the impact of the diagnosis of HIV infection on women, particularly in relation to their reproductive decisions 11,12,13,14,15. In Brazil, several surveys have been documented on sexual behavior in the general population, using different methodologies $8,16,17$. The study with the widest scope that explores sexual and reproductive health questions in Brazil, on HIV-positive women and women without known HIV serological status, was conducted in 2003 and 2004 and involved 13 Brazilian municipalities. In important caveat is that in both studies the health services were chosen by a convenience sample 18 . 
The understanding of women living with HIV treated at specialized public services and their sexual and reproductive health characteristics is fundamental for the development of health promotion strategies for women living with HIV. It is also important to evaluate the differences among women living with HIV according to age group, since the contexts of vulnerability to HIV infection and health demands vary according to women's stage of life. The current article analyzed sexual and reproductive health behavior of women living with HIV treated at specialized public services in the city of Porto Alegre, Rio Grande do Sul State, according to age group.

\section{Methods}

A cross-sectional study was conducted in women of childbearing age (18 a 49 years), divided into two groups: women with and without a known diagnosis of HIV infection. Data were collected from January to November 2011.

The sample calculation used the PROC POWER procedure from SAS, version 9.2 (SAS Inst., Cary, USA) and considered the comparison of the two groups in relation to the principal study outcomes. The initial sample size was 384 women in each group for the detection of a prevalence ratio of 1.6, for an expected exposure prevalence of $12.4 \%$ in the group without a known diagnosis of positive HIV serological status (two-tailed $\alpha=0.05$ and $1-\beta$ power $=0.80$ ). Applying design effect correction for complex sampling (deff) equal to 1.6, the final sample size was estimated at 1,230 women, or 615 women in each group, respectively.

The sampling plan corresponded to a stratified sample with two-stage clusters: health services and women treated at health services. The strata consisted of women with and without a known diagnosis of HIV infection. Within each stratum, the primary selection units were the health services: specialized in HIV/AIDS and primary healthcare services. Within the health services, women were selected by simple random sampling according to the proportion of their consultations at the services.

Women who reported never having had sexual relations and women that reported having sexual relations only with women were not included in the study, since one of the study's objectives was to investigate the specificities of women exposed to heterosexual HIV transmission.

This article only analyzes data from the group of women living with HIV. For this group, 756 women were invited to the interviews, of whom $65(8.6 \%)$ refused to participate in the study, so that the final sample consisted of 691 women. Participants were selected at specialized HIV/ AIDS services in Porto Alegre. The number of participants at each service was defined proportionally according to the number of consultations.

Women were selected by simple random sampling from the health services' appointment agendas. The invitation to participate in the study took place either before or after the consultation, according to each health service's characteristics. From a total of 1,193 appointments scheduled for eligible women, 436 (36.5\%) failed to appear and were replaced in the study by selecting women from subsequent appointments on the agenda.

The study protocol included intensive training of the interviewers, including questions on characterization of the AIDS epidemic, methods for approaching patients at the health services, obtaining free and informed consent, and application of the questionnaire.

After providing informed consent, participants answered an electronic questionnaire, elaborated using the Sphinks Léxica program, version 4.0 (Le Sphinx Développement, Chavanod, France) in a private setting, and the interviewer filled in the answers on a netbook.

The questionnaire covered socio-demographic characteristics, principal outcomes in the sexual and reproductive health history, use of contraceptive methods with different partners, time of the diagnosis of HIV infection, use of medicines, situations of violence, and overall health questions.

A pilot study was used to pretest the questionnaire for the questions' adequacy, aimed at facilitating their understanding. Quality control of the data used a second contact with participants, chosen at random, to certify the answers.

Data analysis used Predictive Analytics SoftWare (PASW) version 18.0 (SPSS Inc., Chicago, USA).

Socio-demographic characteristics and reproductive and health history were presented as absolute values and percentages. Comparisons between age groups used the homogeneity of proportions test based on the Pearson chi-square statistic.

Characteristics of both the first and most recent sexual relations were presented as absolute values and percentages or median and inter-quartile range. Data normality was evaluated with the Shapiro-Wilk test. For continuous variables, the comparison of groups used the Kruskal-Wallis test. For all the analyses, significance was set at $5 \%$.

The study protocol (no. 2008216) was approved by the Institutional Review Board at the Rio Grande do Sul Federal University (UFRGS) 
and other boards of the participating institutions. The study was conducted in compliance with the provisions of Ruling $n .19696$ of the National Health Council, dealing with the guidelines and regulatory standards for research involving humans.

\section{Results}

Table 1 shows the description and comparisons of the socio-demographic characteristics of women living with HIV according to age groups. The sample consisted mainly of white women $(59.2 \%)$ and those with more than 7 years of schooling (59.4\%). The majority of the interviewees $(85.7 \%)$ had family incomes of up to 3.99 times the minimum wage (300 to 1,197 US dollars a month at the time of the study) and performed some kind of paid work (54.1\%). In terms of relationships, $71.1 \%$ of the women were in some kind of relationship at the time of the interview.

Older women were more likely to practice a religion as compared to the younger women ( $\mathrm{p}=$ 0.013). As for paid work, the lowest employment rate was observed in women 45 to 49 years of age ( $\mathrm{p}=0.001$ ). Women in the 40-44 and 45-49-year age groups showed a lower percentage of current relationships as compared to the other age groups $(\mathrm{p}<0.001)$.

Table 2 shows data on childbearing history and health characteristics of women living with HIV, by age group. Among women 18 to 24 years of age, $84.7 \%$ had already been in at least one marital relationship. The majority of women from 30 to 49 years of age $(\mathrm{p}=0.004)$ had a history of at least two relationships.

Significant differences were seen in the number of pregnancies and of children in women of different age groups $(\mathrm{p}<0.001)$. About onefourth of women 18 to 24 years of age had never had children. Among women 45 to 49 years of age, $42.4 \%$ reported 4 or more pregnancies, and $31 \%$ had 4 or more children. The proportions of women according to number of sex partners in the previous 12 months differed between age groups; 3 or more partners was more frequent among women 18 to 29 years of age, while more than $25 \%$ of women 40 to 49 years of age reported no partners in the previous 12 months. In addition, $31.6 \%$ of the women reported 10 or more sex partners in their lives. No significant difference was observed between age groups as to lifetime number of sex partners $(\mathrm{p}=0.129)$.

The proportion of use of antiretroviral medication increased progressively with age, reaching $86.7 \%$ in the 45 -to-49-years group $(\mathrm{p}<0.001)$.
History of illicit drug use was more frequent in the 18-to-34-year group ( $\mathrm{p}<0.001$ ). Exchanging sex for money was more frequent among younger women, from 18 to 29 years old $(p=0.009)$.

Table 3 shows the characteristics of the first sexual intercourse among study participants. Median age at sexual initiation differed between age groups ( $\mathrm{p}<0.001)$, and was higher in women 45 to 49 years old.

A history of sexual initiation with a fixed partner was more frequent among older women $(\mathrm{p}=$ $0.001)$. On the other hand, younger women were more likely to have had their last sexual intercourse with a fixed partner $(\mathrm{p}<0.001)$.

In their first sexual intercourse, $65.5 \%$ of women had not used any contraceptive method. The age groups showed significant differences in the use of contraceptive methods at sexual initiation $(\mathrm{p}<0.001)$. For most women 18 to 24 years of age, the most common contraceptive method had been condoms, while the majority of women 25 years and older had not used any method to avoid becoming pregnant during their first intercourse. Condom use at sexual initiation differed between age groups $(\mathrm{p}<0.001)(75.4 \%$ in women 18 to 24 years of age as compared to only $9.2 \%$ in the 45-to-49-year group).

Table 4 shows the characteristics of the last sexual intercourse in the sample. Women 40 to 49 years of age showed longer median time elapsed between last sexual intercourse and the interview, as compared to the other age groups ( $p<0.001)$. No significant differences were observed between age groups as to use of contraceptive methods in the last sexual intercourse; of the overall sample, $26.9 \%$ had not used any contraceptive method. Tubal ligation as a contraceptive method was infrequent. Condom use in the last sexual intercourse was reported by $62.7 \%$ of the sample, with no significant difference between age groups. Both in the first and most recent sexual intercourse, all age groups showed a high number of women who had used condoms but who did not identify the latter as the main method to avoid pregnancy (Table 3 ).

Figure 1 describes the percentage of condom use at sexual initiation according to current age groups and age differences in relation to the male partners. Younger women appeared to adhere more to condom use, and the rate also increased as the age difference decreased with male partners. Condom use at sexual initiation ranged from $70 \%$ to $90 \%$ among women from 18 to 24 and from $30 \%$ to $55 \%$ in women 25 to 29 years of age. The other age groups showed low rates of condom use, regardless of the age difference with male partners. For example, for women older than 34 years, condom use was less than 
Socio-demographic and economic characteristics of women living with HIV, according to age group.

\begin{tabular}{|c|c|c|c|c|c|c|c|c|}
\hline \multirow[t]{3}{*}{ Variable } & \multicolumn{7}{|c|}{ Age group (years) } & \multirow[t]{3}{*}{$\mathrm{p}$-value ** } \\
\hline & Total & $18-24$ & $25-29$ & $30-34$ & $35-39$ & $40-44$ & $45-49$ & \\
\hline & $\mathrm{n}(\%)$ * & $\mathrm{n}(\%)$ * & $\mathrm{n}(\%)$ * & $\mathrm{n}(\%)$ * & $\mathrm{n}(\%)$ * & $\mathrm{n}(\%)$ * & $\mathrm{n}(\%)$ * & \\
\hline \multicolumn{9}{|c|}{ Race/ Ethnic group (self-reported) } \\
\hline White & $409(59.2)$ & $26(44.1)$ & $47(56.6)$ & $87(57.6)$ & 99 (61.9) & $82(59.4)$ & $68(68.0)$ & 0.085 \\
\hline Non-white & $282(40.8)$ & 33 (55.9) & $36(43.4)$ & $64(42.4)$ & $61(38.1)$ & $56(40.6)$ & $32(32.0)$ & \\
\hline \multicolumn{9}{|l|}{ Practices a religion } \\
\hline No & $298(43.1)$ & $36(61.0)$ & $42(50.6)$ & $70(46.4)$ & $70(43.8)$ & $48(34.8)$ & $32(32.0)$ & 0.013 \\
\hline Yes, occasionally & $225(32.6)$ & $13(22.0)$ & $27(32.5)$ & $48(31.8)$ & $45(28.1)$ & $53(38.4)$ & 39 (39.0) & \\
\hline Yes, regularly & $168(24.3)$ & 10 (16.9) & 14 (16.9) & 33 (21.9) & $45(28.1)$ & $37(26.8)$ & $29(29.0)$ & \\
\hline \multicolumn{9}{|l|}{ 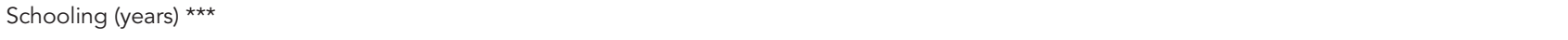 } \\
\hline$\leq 7$ & $280(40.6)$ & $22(37.3)$ & $27(32.5)$ & $59(39.3)$ & $66(41.2)$ & $69(50.0)$ & $37(37.0)$ & 0.131 \\
\hline $8-10$ & $174(25.2)$ & $22(37.3)$ & $25(30.1)$ & $41(27.3)$ & 35 (21.9) & $26(18.8)$ & $25(25.0)$ & \\
\hline$\geq 11$ & $236(34.2)$ & $15(25.4)$ & $31(37.3)$ & $50(33.3)$ & $59(36.9)$ & $43(31.2)$ & $38(38.0)$ & \\
\hline \multicolumn{9}{|c|}{ Household income (times minimum wage) } \\
\hline $0-0.99$ & $88(13.4)$ & $9(16.4)$ & $10(12.3)$ & $19(13.0)$ & $19(12.6)$ & $19(15.1)$ & $12(12.2)$ & 0.301 \\
\hline $1-1.99$ & $261(39.7)$ & $16(29.1)$ & $35(43.2)$ & $65(44.5)$ & $57(37.7)$ & $54(42.9)$ & $34(34.7)$ & \\
\hline $2-3.99$ & $214(32.6)$ & $22(40.0)$ & $23(28.4)$ & $47(32.2)$ & $58(38.4)$ & $35(27.8)$ & $29(29.6)$ & \\
\hline$\geq 4$ & $94(14.3)$ & $8(14.5)$ & $13(16.0)$ & $15(10.3)$ & $17(11.3)$ & $18(14.3)$ & $23(23.5)$ & \\
\hline Currently working & $373(54.1)$ & $25(42.4)$ & $53(63.9)$ & $77(51.3)$ & $101(63.1)$ & $78(56.5)$ & $39(39.0)$ & 0.001 \\
\hline Owns home & $497(73.0)$ & $40(67.8)$ & $58(69.9)$ & $103(70.5)$ & $112(71.3)$ & $106(76.8)$ & $78(79.6)$ & 0.408 \\
\hline \multicolumn{9}{|c|}{ 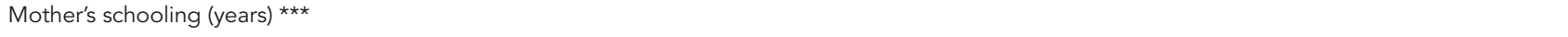 } \\
\hline$\leq 7$ & $329(68.5)$ & $30(68.2)$ & $48(68.6)$ & $75(65.8)$ & $75(66.4)$ & $63(73.3)$ & $38(71.7)$ & 0.841 \\
\hline $8-10$ & $70(14.6)$ & $9(20.5)$ & $9(12.9)$ & $16(14.0)$ & $16(14.2)$ & $11(12.8)$ & $9(17.0)$ & \\
\hline$\geq 11$ & $81(16.9)$ & $5(11.4)$ & $13(18.6)$ & $23(20.2)$ & $22(19.5)$ & $12(14.0)$ & $6(11.3)$ & \\
\hline Currently in relationship & $466(71.1)$ & $48(87.3)$ & $64(82.1)$ & $115(79.3)$ & 108 (71.5) & $76(57.6)$ & $55(58.5)$ & $<0.001$ \\
\hline Total & $691(100.0)$ & $59(8.5)$ & $83(12.0)$ & $151(21.9)$ & $160(23.1)$ & $138(20.0)$ & $100(14.5)$ & \\
\hline
\end{tabular}

* Total numbers may differ between variables due to non-responses;

** $p$-value for test of homogeneity of proportions based on the Pearson chi-square statistic;

*** Years of schooling with passing.

$20 \%$, independently of age difference with male partners.

\section{Discussion}

This study provides evidence that women living with HIV and treated at specialized public health services in southern Brazil display a socioeconomic and sexual behavior profile that does not match the pattern typically identified in the process of "feminization" of the epidemic (featuring poor women with low schooling and lower mean number of sexual partners). The data indicate that women with more schooling and average income and housing conditions are also becoming infected with HIV. A large proportion (34.6\%) of the women treated at the public services had 11 or more years of schooling, only $13.4 \%$ were living with a family income of less than one minimum wage, and $73 \%$ reported owning their homes. In addition, more than $70 \%$ of these women were receiving antiretroviral treatment, indicating that many of them may already be presenting symptoms or clinical manifestations associated with HIV-related immunodeficiency ${ }^{19}$. A study in the State of São Paulo (14) with similar schooling and employment rates also showed a high proportion of women accompanied by public health services who were receiving antiretroviral therapy. The data thus suggested that HIV-positive women with the worst socio-demographic indicators are not being accompanied by the health services. Female AIDS-related mortality in Brazil points in the same direction, namely that women with less schooling are the most affected (Departamento 
Reproductive and health history of women living with HIV according to age group

\begin{tabular}{|c|c|c|c|c|c|c|c|c|}
\hline \multirow[t]{3}{*}{ Variable } & \multicolumn{7}{|c|}{ Age group (years) } & \multirow{3}{*}{$\begin{array}{c}\text { p-value } \\
\star \star\end{array}$} \\
\hline & Total & $18-24$ & $25-29$ & $30-34$ & $35-39$ & $40-44$ & $45-49$ & \\
\hline & $n(\%)$ * & $n(\%)$ * & $n(\%)$ * & $n(\%)$ * & $n(\%)$ * & $n(\%)$ * & $n(\%)$ * & \\
\hline \multicolumn{9}{|c|}{ Number of marriages (or marital relationships) } \\
\hline 0 & $44(6.4)$ & $9(15.3)$ & $5(6.0)$ & $8(5.3)$ & $11(6.9)$ & $5(3.6)$ & $6(6.0)$ & 0.004 \\
\hline 1 & 248 (35.9) & $32(54.2)$ & $37(44.6)$ & $56(37.1)$ & $50(31.2)$ & $45(32.6)$ & $28(28.0)$ & \\
\hline 2 & $267(38.6)$ & $12(20.3)$ & $30(36.1)$ & $60(39.7)$ & $62(38.8)$ & $61(44.2)$ & $42(42.0)$ & \\
\hline$\geq 3$ & $132(19.1)$ & $6(10.2)$ & $11(13.3)$ & $27(17.9)$ & $37(23.1)$ & $27(19.6)$ & $24(24.0)$ & \\
\hline \multicolumn{9}{|l|}{ Number of children } \\
\hline 0 & $83(12.0)$ & $15(25.4)$ & $10(12.0)$ & $14(9.3)$ & $20(12.5)$ & $11(8.0)$ & $13(13.0)$ & $<0.001$ \\
\hline 1 & $187(27.1)$ & $27(45.8)$ & $33(39.8)$ & $47(31.1)$ & $29(18.1)$ & $32(23.2)$ & $19(19.0)$ & \\
\hline 2 & $162(23.4)$ & $14(23.7)$ & $24(28.9)$ & $41(27.2)$ & $41(25.6)$ & $26(18.8)$ & $16(16.0)$ & \\
\hline 3 & $124(17.9)$ & $3(5.1)$ & $11(13.3)$ & $26(17.2)$ & 35 (21.9) & $28(20.3)$ & $21(21.0)$ & \\
\hline$\geq 4$ & $135(19.5)$ & $0(0.0)$ & $5(6.0)$ & $23(15.2)$ & 35 (21.9) & $41(29.7)$ & $31(31.0)$ & \\
\hline \multicolumn{9}{|c|}{ Number of sex partners in previous 12 months } \\
\hline 0 & $105(15.4)$ & $2(3.4)$ & $5(6.0)$ & $12(8.1)$ & $26(16.5)$ & $36(26.5)$ & $24(24.7)$ & $<0.001$ \\
\hline 1 & $501(73.6)$ & $47(81.0)$ & $65(78.3)$ & $124(83.2)$ & $116(73.4)$ & $84(61.8)$ & $65(67.0)$ & \\
\hline 2 & $53(7.8)$ & $4(6.9)$ & $7(8.4)$ & $11(7.4)$ & $12(7.6)$ & $14(10.3)$ & $5(5.2)$ & \\
\hline$\geq 3$ & $22(3.2)$ & $5(8.6)$ & $6(7.2)$ & $2(1.3)$ & $4(2.5)$ & $2(1.5)$ & $3(3.1)$ & \\
\hline \multicolumn{9}{|l|}{ Lifetime number of sex partners } \\
\hline $1-4$ & $290(42.1)$ & $21(35.6)$ & $32(38.6)$ & $64(42.7)$ & $66(41.5)$ & $65(47.1)$ & $42(42.0)$ & 0.129 \\
\hline $5-9$ & $181(26.3)$ & $21(35.6)$ & $19(22.9)$ & $32(21.3)$ & $38(23.9)$ & $44(31.9)$ & $27(27.0)$ & \\
\hline$\geq 10$ & $218(31.6)$ & $17(28.8)$ & $32(38.6)$ & $54(36.0)$ & $55(34.6)$ & $29(21.0)$ & $31(31.0)$ & \\
\hline Use of antiretroviral therapy & $489(71.6)$ & $29(49.2)$ & $50(60.2)$ & $100(66.7)$ & $117(74.5)$ & $108(79.4)$ & $85(86.7)$ & $<0.001$ \\
\hline History of illicit drug use & $203(29.8)$ & $24(40.7)$ & $31(38.3)$ & $59(39.3)$ & $35(22.3)$ & $26(19.0)$ & $28(28.6)$ & $<0.001$ \\
\hline Current illicit drug use & $19(9.4)$ & $1(4.2)$ & $7(22.6)$ & $6(10.2)$ & $2(5.7)$ & $1(3.8)$ & $2(7.1)$ & 0.116 \\
\hline Sex for money & $76(11.2)$ & $9(15.3)$ & $16(19.8)$ & $20(13.4)$ & $18(11.5)$ & $8(5.9)$ & $5(5.1)$ & 0.009 \\
\hline Total & $691(100.0)$ & $59(8.5)$ & $83(12.0)$ & $151(21.9)$ & $160(23.1)$ & $138(20.0)$ & $100(14.5)$ & \\
\hline
\end{tabular}

* Total numbers may differ between variables due to non-responses;

** $p$-value associated with test of independence based on Pearson chi-square statistic.

de Informática do SUS. Mortalidade - Brasil por grupo CID-10: doença pelo vírus da imunodeficiência humana [HIV], sexo feminino, no período de 1996 a 2009. http:/ / tabnet.datasus.gov.br/ cgi/tabcgi.exe?sim/cnv/obt10uf.def, accessed on 7/Jan/2012).

The fact that only half of the women living with HIV in our study were performing some paid work (and that the rate was highest among younger women) may be viewed as indicative of two conditions. The first is that some of the interviewees already have AIDS-defining criteria and are thus eligible for receiving social security benefits in Brazil, such as sick leave and disability pensions 20 . Second, the fact that they are HIV-positive is a barrier to their assimilation or reassimilation by the labor market. According to a French study, HIV-related discrimination in the workplace affects men and women differ- ently: women show a higher risk of losing their jobs 21 , which can also have a negative impact on their reassimilation into the labor market, especially for older women.

As for emotional and sexual relations, AIDS appears not to have the same impact on women as work does. More than $70 \%$ of the women in our sample were living in stable relationships. The comparison by age group showed differences in the patterns of emotional and sexual relations. For nearly $30 \%$ of the older women, the partner in their last sexual relation was their ex-partner, possibly indicating new patterns of relationships for older women. Meanwhile, among most of the younger women, the current partner in their emotional relationship was the same partner as in their last sexual intercourse.

Various risk factors for HIV infection in women have already been identified 22,23,24. A 
Characteristics of first sexual intercourse for women living with HIV, according to age group.

\begin{tabular}{|c|c|c|c|c|c|c|c|c|}
\hline \multirow[t]{3}{*}{ Variable } & \multicolumn{7}{|c|}{ Age group (years) } & \multirow[t]{3}{*}{ P-value } \\
\hline & Total & $18-24$ & $25-29$ & $30-34$ & $35-39$ & $40-44$ & $45-49$ & \\
\hline & $\mathrm{n}(\%)$ * & $n(\%) *$ & $\mathrm{n}(\%)$ * & $\mathrm{n}(\%)$ * & $\mathrm{n}(\%)$ * & $n(\%)$ * & $n(\%)$ * & \\
\hline Age ** & $691(100)$ & $15(2)$ & $15(3)$ & $15(3)$ & $16(3)$ & $16(3)$ & $17(3)$ & $<0.001 * \star \star$ \\
\hline Partner's age ** & $643(100)$ & $19(6)$ & $19.5(6)$ & $19(6)$ & $20(6)$ & $20(5)$ & $20(5)$ & $0.342 * \star \star *$ \\
\hline \multicolumn{9}{|l|}{ Type of partner } \\
\hline Fixed/Stable & $535(77.6)$ & $39(66.1)$ & $55(66.3)$ & $110(73.3)$ & $135(84.4)$ & $116(84.7)$ & $80(80.0)$ & $0.001 \#$ \\
\hline Occasional & $154(22.4)$ & $20(33.9)$ & $28(33.7)$ & $40(26.7)$ & $25(15.6)$ & $21(15.3)$ & $20(20.0)$ & \\
\hline \multicolumn{9}{|c|}{ Principal method used to avoid pregnancy } \\
\hline None & $440(65.5)$ & $16(28.1)$ & $48(58.5)$ & $99(66.9)$ & $100(65.4)$ & $101(75.4)$ & $76(77.6)$ & $<0.001 \#$ \\
\hline Condom & $134(19.9)$ & 37 (64.9) & $25(30.5)$ & $34(23.0)$ & $18(11.8)$ & $11(8.2)$ & $9(9.2)$ & \\
\hline Pill & $79(11.8)$ & $2(3.5)$ & $7(8.5)$ & $11(7.4)$ & $30(19.6)$ & $16(11.9)$ & $13(13.3)$ & \\
\hline More than one method & $14(2.1)$ & $2(3.5)$ & $2(2.4)$ & $3(2.0)$ & $3(2.0)$ & $4(3.0)$ & $0(0.0)$ & \\
\hline Traditional methods & $5(0.7)$ & $0(0.0)$ & $0(0.0)$ & $1(0.7)$ & $2(1.3)$ & $2(1.5)$ & $0(0.0)$ & \\
\hline Used condom & $171(25.5)$ & $43(75.4)$ & $31(37.8)$ & $42(29.0)$ & $26(16.8)$ & $20(14.9)$ & $9(9.2)$ & $<0.001 \#$ \\
\hline Total & $691(100.0)$ & $59(8.5)$ & $83(12.0)$ & $151(21.9)$ & $160(23.1)$ & $138(20.0)$ & $100(14.5)$ & \\
\hline
\end{tabular}

* Total numbers may differ between variables due to non-responses;

** Data presented as medians (inter-quartile range);

*** p-value for Kruskal-Wallis test;

\# p-value for test of homogeneity of proportions based on Pearson chi-square statistic.

Characteristics of last sexual intercourse in women living with HIV, according to age group.

\begin{tabular}{|c|c|c|c|c|c|c|c|c|}
\hline \multirow[t]{3}{*}{ Variable } & \multicolumn{7}{|c|}{ Age group (years) } & \multirow[t]{3}{*}{ p-value } \\
\hline & Total & $18-24$ & $25-29$ & $30-34$ & $35-39$ & $40-44$ & $45-49$ & \\
\hline & $n(\%)$ * & $n(\%) *$ & $n(\%)$ * & $n(\%)$ * & $n(\%)$ * & $n(\%)$ * & $n(\%)$ * & \\
\hline Time since last sexual intercourse ${ }^{\star \star}$ & $688(100)$ & $7(28)$ & $5.5(22)$ & $7(28)$ & $7(87)$ & $21(626)$ & $15(261)$ & $<0.001 * \star \star$ \\
\hline \multicolumn{9}{|l|}{ Who was the partner? } \\
\hline Current partner & $470(69.2)$ & $50(84.7)$ & $66(81.5)$ & $116(78.4)$ & $104(66.7)$ & $76(55.5)$ & $58(59.2)$ & $<0.001 \#$ \\
\hline Ex-partner & $139(20.5)$ & $6(10.2)$ & $11(13.6)$ & $19(12.8)$ & $36(23.1)$ & 41 (29.9) & $26(26.5)$ & \\
\hline Occasional partner & $70(10.3)$ & $3(5.1)$ & $4(4.9)$ & $13(8.8)$ & $16(10.3)$ & $20(14.6)$ & $14(14.3)$ & \\
\hline \multicolumn{9}{|c|}{ Principal method used to avoid pregnancy } \\
\hline None & $175(26.9)$ & $18(31.6)$ & $20(26.7)$ & $38(27.0)$ & $31(20.7)$ & $39(29.1)$ & $29(30.9)$ & 0.060 \# \\
\hline Condom & $343(52.7)$ & $25(43.9)$ & $38(50.7)$ & $73(51.8)$ & $76(50.7)$ & $79(59.0)$ & $52(55.3)$ & \\
\hline Pill & $41(6.3)$ & $4(7.0)$ & $1(1.3)$ & $11(7.8)$ & $13(8.7)$ & $8(6.0)$ & $4(4.3)$ & \\
\hline More than one method & $58(8.9)$ & $7(12.3)$ & $12(16.0)$ & $14(9.9)$ & $17(11.3)$ & $5(3.7)$ & $3(3.2)$ & \\
\hline Tubal ligation & $12(1.8)$ & $0(0.0)$ & $1(1.3)$ & $1(0.7)$ & $5(3.3)$ & $1(0.7)$ & $4(4.3)$ & \\
\hline Other & $22(3.4)$ & $3(5.3)$ & $3(4.0)$ & $4(2.8)$ & $8(5.3)$ & $2(1.5)$ & $2(2.1)$ & \\
\hline Used condom & $450(67.2)$ & $36(62.1)$ & $55(69.6)$ & $97(66.4)$ & $105(67.7)$ & $94(69.1)$ & $63(65.9)$ & $0.935 \#$ \\
\hline Total & $691(100.0)$ & $59(8.5)$ & $83(12.0)$ & 151 (21.9) & $160(23.1)$ & $138(20.0)$ & $100(14.5)$ & \\
\hline
\end{tabular}

* Total numbers may differ between variables due to non-responses;

** Data presented as medians (inter-quartile range);

*** $\mathrm{p}$-value for Kruskal-Wallis test;

\# p-value for test of homogeneity of proportions based on Pearson chi-square statistic. 

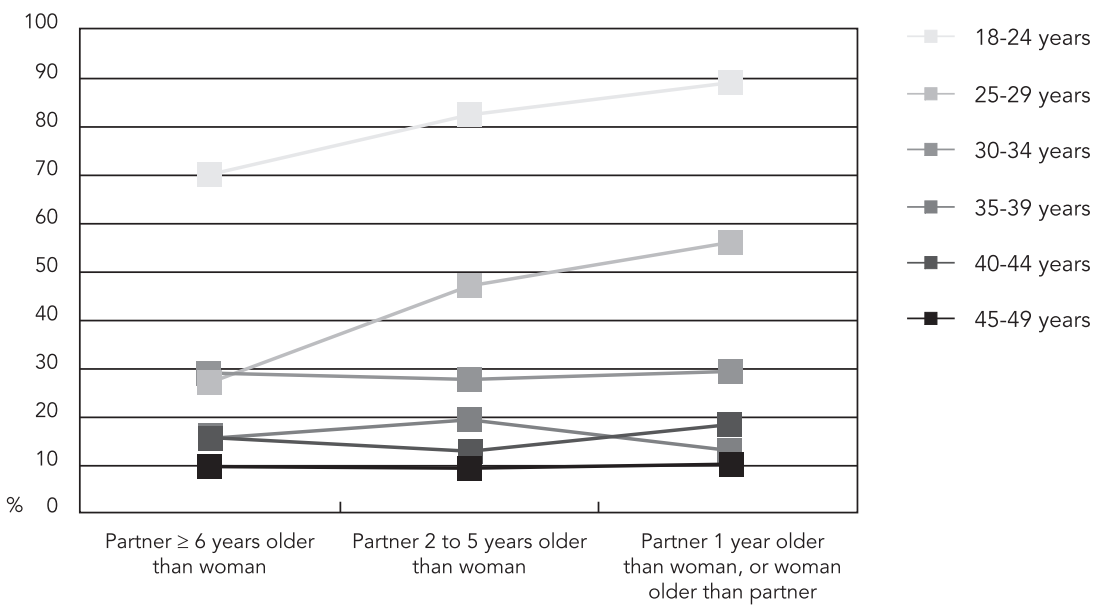

systematic review identified the following risk factors for women in Sub-Saharan Africa: history of multiple sex partners, exchanging sex for money, and presence of other sexually transmitted diseases 25 . The presence or absence of these factors shapes different contexts of women's vulnerability to the epidemic 26 .

This study showed important differences in some factors affecting women's vulnerability to HIV infection, when considering age group. Younger women were more likely to report a history of drug use and to have exchanged sex for money. Meanwhile, some factors were common to the various age groups. As for age at sexual initiation, women living with HIV reported younger age as compared to the same age groups published in population-based surveys on sexuality 8,16 . Studies have shown that early sexual initiation is a factor in contexts of vulnerability to sexually transmitted infections $22,27,28,29$ and pregnancy 28,30 . This phenomenon has been attributed to societal changes such as women's increased participation in the labor market as well as in the area of sexuality, legalization of divorce, and popularization of contraceptive methods 31 .

The lifetime number of sex partners in a context of asymmetrical gender relations with lower power to negotiate condom use 32 is another factor characterizing the vulnerability of women living with HIV. Although the majority of women interviewed in this study reported only one partner in the previous 12 months, $31.6 \%$ of the sample reported 10 or more sex partners in their lives. This number far surpasses those published in other Brazilian studies conducted in the general population (10\%) ${ }^{8}$ and in women living with HIV (19\%) 15. Evidence indicates that lifetime number of sex partners increases with age and the resulting time of sexual exposure 33,34, and that the increase in number of partners is associated with early sexual initiation 29 . In this study's sample, the number of sex partners cannot be explained by the time of sexual exposure, since having had 10 or more sex partners was reported by approximately $30 \%$ of the women in all the age groups, with no significant differences between the groups.

Despite strides in AIDS prevention campaigns in Brazil, a nationwide survey in 2006 identified differences between men and women in sexual behavior and condom use, and differences in female behavior according to age group. Rates of condom use in the first and last sexual intercourse showed large differences, with higher percentages in men. The same survey also showed that especially among younger women, condom use is not maintained over the course of their sex lives, since the percentage of use in the last sexual intercourse was low, particularly with increasing age and in women with less schooling 16.

We found a high number of women that reported condom use in both their first and most recent sexual relations. However, although con- 
dom use at sexual initiation among women living with HIV (especially younger women) was higher than reported in nationwide surveys 8,16 , this practice is not maintained throughout the women's sex lives, since the predominant form of infection is by heterosexual contact 35 .

The proportion of women living with HIV that reported condom use in their last sexual relation $(67.2 \%)$ was far higher than in a Brazilian nationwide survey 16 , and the percentage remained stable in all the age groups. In this sense, positive associations have been documented between condom use by HIV-positive women, increasing with level of schooling and with multiple partners 36 . However, one can ask whether the higher self-reported condom use by women living with HIV might not merely reflect their greater exposure to this preventive discourse rather than true behavior.

Although some studies have shown that women are more prone to use condoms to prevent pregnancy than STDs 37,38 , we observed a large number of women that reported condom use in both their sexual initiation and in their most recent sexual intercourse, while not identifying condoms as the main method for avoiding pregnancy. These data corroborate a survey conducted in Africa, according to which most young people do not always identify condoms as a method to avoid pregnancy, but that nearly $100 \%$ identify them as a method to avoid STDs 39 . This behavior reflects the prevention strategies used in health services, which emphasize the use of male condoms as a specific method to protect against infections, thus dissociating reproduction and sexuality 40 .

Studies indicate that condom use is directly associated with gender issues $41,42,43,44$, and that women are in a position of greater vulnerability in this negotiation. Gender inequalities appear differently among women living with HIV. For older women, negotiation of condom use is nearly inconceivable in the context of sexual relations. For younger women, difficulty in condom use has been associated with risk perception 45,46 , cultural issues 47 , and difficulty in negotiation of use with older partners $30,48,49,50,51,52$, where the smaller the difference in age, the higher the adherence to condom use. And although there are indications that women who have sex with older men are less inclined to use contraceptive meth- ods 27 , further research is needed on the sexual and reproductive health of women in these relations and how gender inequality issues appear in this context.

This study makes important contributions to an analysis of the profile of women living with HIV according to age group, but it also presents some limitations related to the methodology itself. We interviewed women attending health services. During selection, women that did not appear for their appointments were replaced by the subsequent sample randomization process. We obtained our sample from public healthcare services specialized in treating women living with HIV. Due to ethical issues involved in the research theme, we did not include women that had not been treated in health services, since the search for these missing individuals outside the service would have meant disclosing their serological status and conducting home interviews. Women not attending the health services may have been poorer, with less schooling, and with higher AIDS-associated mortality, involving different healthcare needs. The search for these women and knowledge of their health-disease profile is a necessity for the Brazilian health system.

In this study, we observed characteristics in the women's sexual and reproductive behavior that varied according to age group, which would certainly imply different demands on the health services. Older women had a history of more pregnancies and more children and a higher frequency of sexual relations with ex-partners. Younger women had a history of fewer pregnancies and children, more illicit drug use, more exchanging sex for money, and greater frequency of condom use at sexual initiation. The fact that we only studied women living with HIV in a context in which the virus is transmitted predominantly through heterosexual contact demonstrates that this condom use behavior is not maintained throughout their sex lives, which points to the need for new studies to elucidate the trajectory of these women.

In addition, we found similar percentages of lifetime numbers of sex partners between age groups, indicating that the women's sexual behavior (regardless of HIV) increasingly results from changes occurring in the area of sexuality, in which one's sex life is no longer related exclusively to procreation and fertility. 


\section{Resumen}

Estudio transversal que analizó el comportamiento en términos de salud sexual y reproductiva, adoptado por las mujeres viviendo con VIH, según la franja de edad, en la ciudad de Porto Alegre, Río Grande do Sul, Brasil. La muestra estuvo constituida por 691 mujeres. Se observaron diferencias en cuanto al número de gestaciones e hijos. El uso de drogas ilícitas durante la vida fue más frecuente en la franja de los 18 a los 34 años, y la práctica de sexo por dinero fue más frecuente entre las mujeres de 18 a 29 años. Las mujeres viviendo con VIH, atendidas en los servicios públicos especializados en el Sur de Brasil, presentan un perfil socioeconómico y de comportamiento sexual que no corresponde al padrón típicamente identificado en el proceso de feminización de la epidemia, donde se destacan, particularmente, mujeres pobres, con baja escolaridad y bajo número de compañeros sexuales. El estudio proporciona evidencias de que algunos factores, que caracterizan la vulnerabilidad de las mujeres a la infección por el VIH, son bastante diferenciados cuando consideramos la franja de edad, lo que implica acciones específicas de atención en los servicios de salud.

Salud Sexual y Reproductiva; VIH; Mujeres; Conducta Sexual

\section{Referências}

1. Joint United Nations Programme on HIV/AIDS. UNAIDS data tables 2011. Geneva: Joint United Nations Programme on HIV/AIDS; 2011.

2. Joint United Nations Programme on HIV/AIDS. Global HIV/AIDS response. Epidemic update and health sector progress towards Universal Access. Program report 2011. http://www.unaids.org/ en/media/unaids/contentassets/documents/ unaidspublication/2011/20111130_UA_Report_ en.pdf (accessed on 05/Jan/2012).

3. Wingood GM. Feminization of the HIV epidemic in the United States: major research findings and future research needs. J Urban Health 2003; 80 (4 Suppl 3):S67-77.

4. Departamento de DST, AIDS e Hepatites Virais, Ministério da Saúde. Resumo analítico dos dados do Boletim Epidemiológico 2011. Brasília: Ministério da Saúde; 2011

5. Possas C, Buchalla CM, Hearst N. Building AIDS research capacity in Brazil. J Acquir Immune Defic Syndr 2011; 57 Suppl 3:125-8.

6. Galvão J. 1980-2001: uma cronologia da epidemia de HIV/AIDS no Brasil e no mundo. Rio de Janeiro: Associação Brasileira Interdisciplinar de AIDS; 2002.

\section{Contributors}

L. B. Teixeira, F. B. Pilecco, A. Vigo, and D. R. Knauth contributed to the study project's conceptualization, data analysis, interpretation, writing of the article, critical revision pertaining to the intellectual contact, and final approval of the version for publication.

\section{Acknowledgments}

The authors wish to thank Grupo Hospitalar Conceição (GHC) for its support and the Brazilian National Research Council (CNPq) for the research funding.
7. Ministério da Saúde. Plano Integrado de enfrentamento da feminização da epidemia de AIDS e outras DST. Brasília: Ministério da Saúde; 2009.

8. Pascom ARP, Arruda MR, Simão MBG, organizadores. Pesquisa de conhecimentos, atitudes e práticas na população brasileira de 15 a 64 anos 2008 . Brasília: Ministério da Saúde; 2011.

9. Joint United Nations Programme on HIV/AIDS. Global plan towards the elimination of new HIV infections among children by 2015 and keeping their mothers alive. Geneva: Joint United Nations Programme on HIV/AIDS; 2011.

10. Fundo de População das Nações Unidas; EngenderHealth. Saúde sexual e saúde reprodutiva das mulheres adultas, adolescentes e jovens vivendo com HIV e AIDS: subsídios para gestores, profissionais de saúde e ativistas. Brasília: Fundo de População das Nações Unidas/New York: EngerderHealth; 2008.

11. Feldman R, Maposhere C. Safer sex and reproductive choice: findings from "positive women: voices and choices" in Zimbabwe. Reprod Health Matters 2003; 11:162-73. 
12. Gogna ML, Pecheny MM, Ibarlucía I, Manzelli H, López SB. The reproductive needs and rights of people living with HIV in Argentina: health service users' and providers' perspectives. Soc Sci Med 2009; 69:813-20.

13. Paiva V, Santos N, França-Junior I, Filipe E, Ayres JR, Segurado A. Desire to have children: gender and reproductive rights of men and women living with HIV: a challenge to health care in Brazil. AIDS Patient Care STDS 2007; 21:268-77.

14. Marcellin F, Protopopescu C, Abé C, Boyer S, Blanche J, Ongolo-Zogo, et al. Desire for a child among HIV-infected women receiving antiretroviral therapy in Cameroon: results from the national survey EVAL (ANRS 12-116). Aids Care 2010; 22:441-51.

15. Fiore S, Heard I, Thorne C, Savasi V, Coll O, Malyuta R, et al. Reproductive experience of HIV-infected women living in Europe. Hum Reprod 2008; 23:2140-4.

16. Ministério da Saúde. Pesquisa Nacional de Demografia e Saúde da Criança e da Mulher - PNDS 2006: dimensões do processo reprodutivo e da saúde da criança. Brasília: Ministério da Saúde; 2009.

17. Berquó E, Barbosa RM, Lima LP. Uso do preservativo: tendências entre 1998 e 2005 na população brasileira. Rev Saúde Pública 2008; 42 Suppl 1: 34-44.

18. Santos NJS, Barbosa RM, Pinho AA, Villela WV, Aidar T, Filipe EMV. Contextos de vulnerabilidade para o HIV entre mulheres brasileiras. Cad Saúde Pública 2009; 25 Suppl 2:S321-33.

19. Programa Nacional de DST e AIDS, Secretária de Vigilância em Saúde, Ministério da Saúde. Recomendações para terapia antirretroviral em adultos infectados pelo HIV. 7a Ed. Brasília: Ministério da Saúde; 2008.

20. Ministério da Previdência Social. Diretrizes de apoio à decisão médico-pericial em clínica médica em HIV/AIDS. http://www.previdencia.gov.br/ar quivos/office/4_110831-181722-268.pdf (accessed on $07 / \mathrm{Jan} / 2012$ ).

21. Dray-Spira R, Gueguen A, Lert F; VESPA Study Group. Disease severity, self-reported experience of workplace discrimination and employment loss during the course of chronic HIV disease: differences according to gender and education. Occup Environ Med 2008; 65:112-9.

22. Pettifor AE, van der Straten A, Dunbar MS, Shiboski SC, Padian NS. Early age of first sex: a risk factor for HIV infection among women in Zimbabwe. AIDS 2004; 18:1435-42.

23. Laga M, Manoka A, Kivuvu M, Malele B, Tuliza M, Nzila N, et al. Non-ulcerative sexually transmitted diseases risk factors for HIV-I transmission in women: results from a cohort study. AIDS 1993; 7:95-102.

24. De Vicenzi I. A longitudinal study of human immunodeficiency virus by heterosexual partners. $\mathrm{N}$ Engl J Med 1994; 331:341-6.

25. Chen L, Jha P, Stirling B, Sgaier SK, Daid T, Kaul R, et al. Sexual risk factors for HIV infection in early and advance HIV epidemics in Sub-Saharan Africa: systematic overview of 68 epidemiological studies. PLoS One 2007; 2:e1001.
26. Ayres JR, França Jr. I, Calazans G, Salletti Filho H. Vulnerabilidade e prevenção em tempos de AIDS. In: Barbosa RM, Parker R, organizadores. Sexualidade pelo avesso: direitos, identidades e poder. São Paulo: Editora 34; 1999. p. 49-72.

27. Gómez AM, Speizer IS, Reynolds H, Murray N, Beauvais $\mathrm{H}$. Age differences at sexual debut and subsequent reproductive health: is there a link? Reprod Health 2008; 5:8.

28. Rector RE, Johnson KA, Noyes LR, Martin S. The harmful effects of early sexual activity and multiple sexual partners among women: a book of charts. Washington DC: The Heritage Foundation; 2002.

29. Wand H, Ramjee G. The relationship between age of coital debut and HIV seroprevalence among women in Durban, South Africa: a cohort study. BMJ Open 2012; 2:e000285.

30. Aquino EML, Heilborn ML, Knauth DR, Bozon M, Almeida MC, Araújo J, et al. Adolescência e reprodução no Brasil: a heterogeneidade dos perfis sociais. Cad Saúde Pública 2003; 19 Suppl 2:S377-88.

31. Bozon M. Sociologia da sexualidade. Rio de Janeiro: Editora FGV; 2004.

32. Barbosa RM. Negociação sexual e sexo negociado, sexualidade e gênero em tempos de AIDS [Doctoral Dissertation]. Rio de Janeiro: Universidade Federal do Rio de Janeiro; 1997.

33. Gregson S, Todd J, Zaba B. Sexual behaviour change in countries with generalised HIV epidemics? Evidence from population-based cohort studies in sub-Saharan Africa. Sex Transm Infect 2009; 85 Suppl 1:i1-2.

34. Mishra V, Hong R, Assche SBV, Barrere B. The role of partner reduction and faithfulness in HIV prevention in Sub-Saharan Africa: evidence from Cameroon, Rwanda, Uganda, and Zimbabwe. Calverton: Macro International Inc.; 2009. (DHS Working Papers).

35. Departamento de DST, AIDS e Hepatites Virais, Ministério da Saúde. Boletim Epidemiológico AIDS e DST 2011; Ano VII, n. 1.

36. Kapiga SH, Lwihula GK, Shao JF, Hunter DJ. Predictors of AIDS knowledge, condom use and high-risk sexual behaviour among women in Dar-es-Salaam, Tanzania. Int J STD AIDS 1995; 6:175-83.

37. Cooper ML, Agocha VB, Powers AM. Motivations for condom use: do pregnancy prevention goals undermine disease prevention among heterosexual young adults? Health Psychol 1999; 18:464-74.

38. Bull SS, Shlay JC. Promoting "dual protection" from pregnancy and sexually transmitted disease: a social ecological approach. Health Promot Pract 2005; 6:72-80.

39. Maharaj P. Reasons for condom use among young people in KwaZulu-Natal: prevention of HIV, pregnancy or both? Int Fam Plan Perspect 2006; 32: 28-34.

40. Askew I, Berer M. The contribution of sexual and reproductive health services to the fight against HIV/AIDS: a review. Reprod Health Matters 2003; 11:51-73.

41. Pettifor AE, Measham DM, Rees HV, Padian NS. Sexual power and HIV risk, South Africa. Emerg Infect Dis 2004; 10:1996-2004. 
42. Kim J, Pronyk P, Barnett T, Watts C. Exploring the role of economic empowerment in HIV prevention. AIDS 2008; 22 Suppl 4:S57-71.

43. Jewkes RK, Levin JB, Penn-Kekana LA. Gender inequalities, intimate partner violence and HIV preventive practices: findings of a South African crosssectional study. Soc Sci Med 2003; 56:125-34.

44. Mumtaz Z, Slaymaker E, Salway S. Condom use in Uganda and Zimbabwe: exploring the influence of gendered access to resources and couple-level dynamics. In: Kishor S, editor. A focus on gender: collected papers using DHS data. Calverton: ORC Macro; 2005. p. 117-46.

45. Reisen CA, Poppen PJ. Partner-specific risk perception: a new conceptualization of perceived vulnerability to STDs. J Appl Soc Psychol 1999; 29:667-84.

46. Meekers D, Klein M. Determinants of condom use among young people in urban Cameroon. Stud Fam Plan 2002; 33:335-46.

47. Gregson S, Nyamukapa CA, Garnett GP, Mason PR, Zhuwau T, Caraël M, et al. Sexual mixing patterns and sex-differentials in teenage exposure to HIV infection in rural Zimbabwe. Lancet 2002; 359:1896-903.
48. Nkosana J, Rosenthal D. The dynamics of intergenerational sexual relationships: the experience of schoolgirls in Botswana. Sex Health 2007; 4:181-7.

49. Leclerc-Madlala S. Age-disparate and intergenerational sex in southern Africa: the dynamics of hypervulnerability. AIDS 2008; 22 Suppl 4:S17-25.

50. Nobelius AM, Kalina B, Pool R, Whitworth J, Chesters J, Power R. Sexual partner types and related sexual health risk among out-of-school adolescents in rural south-west Uganda. AIDS Care 2011; 23:252-9.

51. Dunkle KL, Jewkes RK, Brown HC, Gray GE, McIntryre JA, Harlow SD. Gender-based violence, relationship power, and risk of HIV infection in women attending antenatal clinics in South Africa. Lancet 2004; 363:1415-21.

52. Longfield K, Glick A, Waithaka M, Berman J. Relationships between older men and younger women: implications for STIs/HIV in Kenya. Stud Fam Plann 2004; 35:125-34.

Submitted on 20/Jun/2012

Final version resubmitted on 24/Sep/2012

Approved on 17/Oct/2012 